OF MICE AND MEN: REFLEXIONES SOBRE LA ÉTICA DE LA EXPERIMENTACIÓN ANIMAL

\author{
AUTOR: Lluis Ferrer \\ TÍTULO: Of Mice and Men: reflexiones sobre la ética de la experimentación animal
}

FECHA DE PUBLICACIÓN: 2010

LUGAR DE PUBLICACIÓN: Revista de la Sociedad Española de Ciencias del Animal de Laboratorio (SECAL)

Reproducido con autorización expresa del autor en: derecho Animal web Center, febrero 2010

\title{
OF MICE AND MEN: REFLEXIONES SOBRE LA ÉTICA DE LA EXPERIMENTACIÓN ANIMAL
}

\author{
Lluís Ferrer
}

Universitat Autònoma de Barcelona

Desde siempre me ha fascinado la combinación de ciencia y literatura. Creo que es una amalgama sumamente estimulante y que ambas están más próximas de lo que parece: muchos avances científicos y tecnológicos y muchos episodios históricos ya se habían imaginado y explicado en la literatura antes de que acontecieran. Incluso en nuestros recuerdos se mezclan y resulta en ocasiones difícil discernir si un hecho ocurrió en la realidad o en la fícción. Por eso he añadido a este escrito el ante-título de "Of mice and men", en referencia y homenaje al clásico de John Steinbeck. Steinbeck fue un escritor seducido por la ciencia y por la investigación científica y debería ser lectura casi obligada para científicos y naturalistas. En varias de sus noveles los protagonistas son científicos y con frecuencia explica el mundo de la investigación, que conocía bien a través de un amigo suyo biólogo. Su espléndido "Cannery Row", por ejemplo, narra las aventuras y desventuras de un grupo de naturalistas en la California de la gran depresión de los años 30 y "Por el mar de Cortez" es el diario de unos naturalistas que navegan 
por el Golfo de California y de su lucha por catalogar especies marinas hasta entonces desconocidas.

Por ello, cuando me propusieron escribir sobre de la experimentación animal, en seguida me vino a la cabeza el título del libro de Steinbeck "Of mice and men". Se trata de una novela corta que explica las miserias de una pareja de amigos, jornaleros agrícolas en el Valle de Salinas californiano y que, por encima de todo, es un canto a la amistad. Canto que acaba en tragedia cuando Lennie, uno de los dos protagonistas, es acusado y perseguido por una agresión a una mujer. Una novela que, como muchas de Steinbeck, nos muestra la intensa relación que existe entre las personas y las fuerzas de la naturaleza, nuestros vínculos con los animales y con el entorno natural en su conjunto.

Compartimos este planeta con millones de especies de animales. Hemos crecido y evolucionado juntos $\mathrm{y}$ nos hemos ido adaptando juntos. $\mathrm{Y}$ por mucho que algunas religiones, filosofías y creencias se esfuercen de marcar una enorme separación entre personas y animales, el hecho cierto es que somos muy parecidos. Pero paradójicamente, este hecho, lejos de alegrarnos, nos incomoda. La gente, nosotros, nos sentimos incómodos cuando los avances científicos detectan, día a día, nuevas muestras de similitud. Hace dos siglos costó aceptar nuestro origen común y, de hecho, buena parte de las religiones no lo ha aceptado todavía y se aferran a teorías creacionistas. Hoy en día, aceptada la teoría de la evolución, en los países occidentales todavía nos cuesta aceptar que los animales comparten con nosotros mucho más que moléculas. Nos cuesta aceptar que puedan tener dolor, angustia, ansiedad, pena, compasión, solidaridad,... sentimientos que queremos conservar en exclusiva. Por ello, cuando algún científico muestra una gorila del zoo consolando a una amiga desolada por la muerte de su cría, tendemos a la incredulidad o a hacer bromas y chistes descalificadores.

¿Porqué nos comportamos así? Básicamente porque tenemos mala consciencia. El derecho romano, tan sabio, decidió que los animales eran equiparables a "cosas" y que los animales no podían tener derechos pero sí propietarios. Así en la sistematización del jurista Gayo (siglo II después de Cristo), a los animales (junto con los esclavos) se les 
otorga el estatuto jurídico de “cosas”. Más tarde, cuando después de la revolución francesa Napoleón decide uniformizar y regionalizar el derecho, reproduce los textos romanos y sigue manteniendo a los animales como "bienes útiles", categoría en la que han permanecido hasta nuestros días. Son, para la ley, propiedades carentes de sentimientos y de derechos. Hasta ahora, las únicas excepciones (tímidas pero relevantes) han sido las reformas constitucionales de Alemania, Austria y Suiza, que han reconocido por primera vez a los animales un estatus diferente, de "seres con sentimientos". Un pequeño gran paso, sobre todo para la dignidad de las personas.

Esto en el ámbito jurídico. En el terreno religioso la situación todavía es más desfavorable. Muchas han negado la capacidad de sentir de los animales y otras, como la católica, han destacado siempre el origen divino del hombre. En este sentido una lectura muy sugerente y refrescante es la famosa "Disputa de l'ase" ("Disputa del asno") un ensayo escrito en el año 1417 por el padre franciscano mallorquín Anselm Turmeda, que hizo el viaje inverso al que hoy hacen las pateras y emigró al norte de África, a Túnez, y se convirtió al Islam, con el nombre de Abd-Allah at Tarjuman. El libro explica como un día, Turmeda, paseando por un parque encuentra una asamblea de animales que están eligiendo al su nuevo rey. Como de inmediato Turmeda declara la superioridad del hombre, los animales reunidos designan al asno para que tenga una disputa dialéctica con el monje. Turmeda expone diecinueva razones de la superioridad humana, las cuales son sistemáticamente refutadas por el inteligente asno, que cita convincentes ejemplos de la superioridad de los animales frente a las limitaciones, en muchos aspectos, del hombre. Al final Turmeda vence con el argumento de que dios eligió convertirse en hombre cuando quiso venir a la tierra, pero los excesos de la vanidad humana quedan al descubierto a lo largo de la disputa. Este hecho llevó a que la Inquisición incluyera la obra en la lista de "Libros prohibidos" de 1583.

El caso es que la consideración generalizada de los animales como cosas era tranquilizadora y muy útil, a la vista de nuestros planes como especie. Por el contrario, si se va demostrando y aceptando que los animales tienen sentimientos, emociones, comportamientos racionales... ¿cómo vamos a justificar, no ya nuestra preeminenciaque es obvia-, sino el uso que de ellos hacemos y el trato de que les deparamos? 
Ciertamente nos incomoda que, siendo tan parecidos, los tratemos de forma tan diferente, tan cruel en ocasiones. Y preferimos ignorarlo. Nuestro comportamiento con las otras especies animales no es como para sentirnos orgullosos. En muchos casos les hemos ocupado o destruido sus ecosistemas vitales. En otros, sencillamente los utilizamos, como alimento, como fuerza de trabajo o como simple diversión. Sólo de forma excepcional y reciente hemos sido capaces de desplegar sentimientos de estima hacia ellos y frecuentemente se leen críticas que llegan a valorar como "desviaciones" estas relacionas más profundas entre, por ejemplo, personas y animales de compañía.

Entre los usos que hacemos de los animales, el caso de los animales de experimentación es singular. En las sociedades occidentales, por ejemplo, existe un gran consenso sobre la no aceptación del sufrimiento animal provocado para la diversión de las personas. Así, de forma progresiva se van erradicando todos los espectáculos que comportan sufrimiento, crueldad o vejación de los animales. De igual manera, la ganadería ha ido introduciendo el concepto de "bienestar animal" (un eufemismo cuando el destino que te espera a ti y a tus crías es el sacrificio en el matadero..) y poco a poco los sistemas de producción animal intentan minimizar el sufrimiento de los animales... aunque una parte de la población querría ir mucho más lejos y el número de vegetarianos y de veganos ("vegetarianos estrictos") no deja de crecer: solo en el Reino Unido ya hay más de 6 millones. Pero en cualquier caso hay un consenso bastante elevado sobre como proceder.

El caso de la experimentación animal es diferente y especial. Porque incluso los proteccionistas más radicales acceptan que la experimentación animal genera beneficios al progreso de la humanidad de los cuales es muy difícil prescindir. A modo de ejemplo, el conocido animalista y catedrático de Filosofía de la Universidad de Barcelona, Jesús Mosterin escribe en su libro "Vivan los animales":

"En el caso de los experimentos científicamente importantes se plantea un conflicto moral genuino, sin solución satisfactoria, entre nuestra valoración del avance del conocimiento y nuestro rechazo del sufrimiento provocado”... 
Es decir, incluso un reconocido proteccionista como Jesús Mosterín (o como podría ser yo mismo) reconoce el valor indudable de la experimentación con animales (la plenamente justificada, lógicamente) para conseguir avances, a pesar del coste en sufrimiento animal que tiene. De momento este dilema ético no tiene una solución completamente satisfactoria. Sencillamente veremos como se puede atenuar.

Sin embargo, lo que crea más desconcierto en la comunidad científica no es la crítica de los proteccionistas radicales. Es el rechazo de una parte muy importante de los ciudadanos, principales beneficiarios de la investigación. A modo de ejemplo, en la última consulta que se realizó sobre este tema en Suiza, en 1992, los partidarios de mantener la experimentación con animales ganaron únicamente con un $56 \%$ de los votos. Un $44 \%$ de los ciudadanos votó en contra. Hoy en día ya nadie se atrevería a convocar un nuevo referéndum de estas características por el fundado temor a una victoria abolicionista.

Sea cuales sean las razones, el hecho es que un $44 \%$ de los ciudadanos suizos estaban dispuestos a abolir la experimentación con animales. Pero lo más curiosos es que la mayoría de ellos no quería renunciar a los avances y beneficios de la ciencia médica y, de hecho, esperaba no tener que renunciar. Una esperanza poco fundamentada, puesto que todos sabemos que la experimentación animal (o, al menos buena parte de ella) es necesaria para mantener el ritmo de avance de la medicina. Obviamente, aceptando matizaciones, como que la experimentación con animales podría reducirse y que en muchos casos el sufrimiento animal podría mitigarse. Pero resulta incuestionable su utilidad para el avance de la medicina.

¿Porqué entonces muchos ciudadanos creen que es posible suprimir la experimentación con animales y seguir disfrutando de los progresos de la ciencia médica?. Seguramente hay varias respuestas a esta pregunta pero pienso que dos son especialmente relevantes.

Una primera explicación es de carácter general y es la creciente incoherencia que se detecta en los comportamientos de los ciudadanos de las sociedades occidentales. La 
ausencia de coherencia entre lo que se hace y lo que se exige a los otros ciudadanos y al conjunto de la sociedad. Ciudadanos que no bajan del coche ni para comprar el pan, que tienen el termostato del aire acondicionado a $19^{\circ} \mathrm{C}$ y que cogen un avión cada cuatro días se manifiestan contra el cambio climático o contra la construcción de una central nuclear o de un aerogenerador en su municipio. Incoherencias que resultan especialmente dolorosas en el caso de la ciencia. Así, todos conocemos el caso de personas que se benefician plenamente de la tecnología y de la ciencia pero que luego consultan su futuro -por Internet- a un astrólogo vestido de forma carnavalesca. Un amigo mío ingeniero que trabaja de forma rigurosa en el control de calidad de una empresa alimentaria trata de sus enfermedades con hierbas de composición desconocida recetadas por un naturópata. Nos gustan los resultados de la ciencia pero ni entendemos la ciencia ni estamos dispuestos a comportarnos de una manera científica en nuestra vida cotidiana.

Bertrand Russell ya evidenció esta contradicción en su famoso clásico "The scientific outlook": el pensamiento científico no es natural en las personas, es el resultado de un largo proceso educativo y, a pesar de que la sociedad progresa en gran medida gracias a la ciencia y la tecnología, no se puede hablar de una sociedad científica. Por todo ello, muchos ciudadanos no ven una contradicción en rechazar la experimentación animal pero seguir esperando avances de la ciencia médica y seguir beneficiándose de ellos.

La segunda explicación pienso que hay que buscarla en al ausencia de una información contrastada y ponderada sobre la experimentación con animales y por el contrario, la proliferación de informaciones tendenciosas, sesgadas, falsas o sensacionalistasalarmistas. Por parte de grupos abolicionistas se exagera el sufrimiento animal, frecuentemente de forma demagógica. Así, todo el mundo recuerda las impactantes imágenes de los monos inmovilizados y con electrodos intracraneales, que hacen pensar que el uso de primates en experimentos agresivos es práctica habitual en laboratorios y universidades. Además, se magnifica la falta de control y la ocultación de la experimentación, en muchos casos con ejemplos reales, pero que son excepciones y no la regla y se difunden ejemplos de experimentaciones inútiles realizadas con animales (que también las hay, para que negarlo). 
Desde la comunidad científica y de la industria farmacéutica tampoco se ha ayudado mucho. La política de la ocultación y de las puertas cerradas, a la larga pasa factura. Y mucho más todavía la resistencia cumplir con la normativa y a colaborar activamente en su cumplimiento. Cada irregularidad, cada ocultación descubierta ha sido munición para grupos abolicionistas radicales y ha debilitado la credibilidad de autoridades, laboratorios y científicos.

¿Qué podemos hacer desde posiciones que pretenden ser coherentes y responsables? Sin ánimo ninguno de sentar cátedra, sino con la voluntad de favorecer un debate sosegado y razonado que permita avanzar al máximo a la ciencia médica con el mínimo sufrimiento de animales y el máximo respeto hacia ellos, creo que unas recomendaciones útiles podrían ser las siguientes:

1. Cumplir siempre y de forma estricta la normativa legal vigente y colaborar en su cumplimiento. No hacerlo nos deslegitima en cualquier debate público que se pueda producir.

2. Aceptar abiertamente la existencia del conflicto ético señalado por Mosterín. Ayudar desde la profesionalidad, el rigor y la seriedad a minimizarlo ("reduce, replace, refine").

3. Los científicos tienen que participar en el debate público, defendiendo de forma argumentada sus puntos de vista y explicando porque creen que hay que continuar con la experimentación con animales y cuáles son los beneficios que de ella se derivan.

4. Acercar más ciencia y sociedad. Aumentar la divulgación científica e implementar sistemas de participación de los ciudadanos en la aprobación y concesión de programas de investigación y de ayudas. Hay que investigar sobre los problemas que preocupan a los ciudadanos e, inversamente, no se deben llevar acabo investigaciones que la sociedad no desea, por beneficiosas que 
pensemos que pueden ser. Los métodos de investigación deben también ser conocidos y aprobados.

5. Admitir y explicitar que la decisión final de investigar con animales pertenece a la sociedad democrática y no a los científicos. Actuar con humildad y sin soberbia.

Por cierto, ahora que llegamos al final, me doy cuento de que no he explicado porque Steibeck puso este título a su libro. Of mice and men hace a referencia a un poema de Robert Burns (recogido en la primera página del libro) que explica la mala fortuna de un ratón de campo al cual un arado le destruye de forma completa su madriguera. El poema habla de la imprevisibilidad del futuro y de la fragilidad de nuestros planes e ilusiones y de como se pasa en unos instantes de la felicidad al dolor.

Según Steinbeck personas y ratones compartimos una gran vulnerabilidad y un destino incierto en este mundo. Y esto, ciertamente, es compartir mucho. ¿No creen?.

\section{$\underline{\text { Referencias bibliográficas }}$}

Mosterin J. ¡Vivan los animales!. Editorial Debate, Barcelona, 1998

Russell B. The scientific outloook. Taylor and Francis e-Library, 2009

Steinbeck J. Of mice and men. Penguin Classics, London, 1996

Steibeck J. Cannery row. Penguin, London, 2000

Steinbeck J. The log from the Sea of Cortez. Penguin, London, 2002

Turmeda A. La disputa de l'ase. Editorial Barcino, Barcelona, 2002 